\title{
In Memoriam: David A. J. Macey
}

Frontiers lost a long-time colleague and supporter when David Macey, former Director of Off-Campus Studies at Middlebury College, passed away on August 10, 2008.

\section{David Macey: A Remembrance}

At a professional conference around a dozen years ago a number of us had gathered at the hotel lounge at the end of a long day of sessions and workshops that focused mainly on administrative and logistical aspects of education abroad. From the other side of the room I heard something I had not experienced before at these often bland professional meetings. I was taken aback by the raised voices and passionate exclaims that caused many of us in the room to turn our heads and stare. It was a genuine, heated argument that was in full swing among five or six colleagues. The topic, of all things, seemed to have something to do with academic standards for study abroad programs. In the middle of the group I quickly identified the instigator of this animated exchange, an unmistakable fellow in casual dress, a full beard and broad smile, and a wild gleam in his eyes. I and others moved over to join the fray, and I knew that I had to meet the rabble rouser who seemed quite content in how he had stirred up the crowd. That was the first time that I met David Macey, and that evening began a friendship with him that I valued greatly.

David was a gift to the field at a time when many of us came together to focus more attention on the academic nature of education abroad. He contributed mightily to efforts to raise the standards of the field. He was for many of us the conscience of education abroad, always reminding us that our programs should be as academically rigorous as possible. This was not an abstract idea for David. He loved to tell detailed stories about individual students and their successes, and I relished the opportunity to hear him describe the many examples of how Middlebury students were transformed by their overseas learning. I found inspiration for my own work in those stories, and I know many other colleagues did as well.

David was one of the most influential activists in our field. He threw his support and energy behind important initiatives at critical times. 
When he did, it was a signal to everyone that the initiative was a serious and worthy one. If David Macey and Middlebury were on board, then people took notice, and they also wanted to be involved.

I and the editorial board will remain grateful always for David's faithful support of Frontiers. When the journal went through an uncertain period and needed institutional sponsors, David offered the support of Middlebury. He took an active personal interest in Frontiers, and often served as an outstanding manuscript reviewer. His support and involvement were important to making Frontiers the success that it has become.

David's early and enthusiastic support of The Forum on Education Abroad was important to what was then a fledgling organization. Kathy Sideli of Indiana University, the founding Chair of the Board of the Forum, wrote, "I remember that getting David to commit Middlebury early on was a real indication to me that the founding board members of the Forum had hit on something significant." David went on to serve as a peer reviewer in the Forum's Standards Pilot Project, and attended the Forum meetings and conferences, where he made significant contributions. The Forum feels David's loss deeply and will long remember him.

I had tremendous affection for David as a colleague and as a person. I loved to hear him laugh, and took glee in trying to make him do so. We shared a running joke and a friendly rivalry between our two institutions, Dickinson and Middlebury. Whenever we met I would tease him by pointing out ways that Dickinson was far more advanced in education abroad, and he would be ready with a comeback describing how far ahead of Dickinson Middlebury was. After David retired as Director of Off-Campus Study, he called me to say that he would like to visit Dickinson with his successor, Jeff Cason, to exchange ideas about study abroad. Hosting David and Jeff at Dickinson was a true pleasure, but David asked me with a sly smile to please not tell anyone about their coming down, lest people have the impression that Middlebury was trying to learn something about study abroad from Dickinson.

I and many Frontiers readers remember David as the ideal education abroad professional, someone who focused on students, believed in academic rigor, was collegial with and supportive of others, and who was not afraid to raise critical issues and questions about the status quo. 
Most of all, I suspect that we will remember David's hearty laugh, that gleam in his eyes, and the genuine pleasure that he took in making life more meaningful for all of us.

Brian Whalen 